\title{
Reinforcement of Character Education Based on School Culture to Enhancing Elementary School Students' Citizenship
} Character

\section{Lisa Retnasari ${ }^{1}$, Yayuk Hidayah ${ }^{2}$, Danang Prasetyo ${ }^{3}$}

1,2 PGSD, Universitas Ahmad Dahlan Yogyakarta, Indonesia

${ }^{3}$ MKU PPKn, STIPRAM Ambarrukmo Yogyakarta, Indonesia

\section{ART I CLE I N F O}

Article history:

Received March 15, 2021

Revised March 18, 2021

Accepted April 30, 2021

Available online May 25, 2021

\section{Kata Kunci}

Karakter, Kewarganegaraan, Budaya Sekolah

Keywords:

Character, Citizenship, Schoo Culture

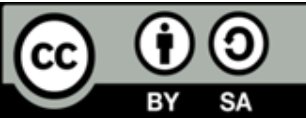

This is an open access article under the CC BY-SA license.

Copyright $(2021$ by Author. Published by Universitas Pendidikan Ganesha.

\section{A B S T R A C T}

\begin{abstract}
A B S T RA K
Pembangunan karakter bangsa belum menunjukkan kemajuan kemajuan warganya menjadi lebih berkarakter. Fenomenanya, banyak perilaku warga yang tidak sesuai dengan karakter yang dijiwai oleh falsafah Pancasila. Tujuan penelitian ini yaitu menganalisis program penguatan pendidikan karakter berbasis budaya sekolah sebagai penguat karakter kewargaan siswa sekolah dasar. Metode yang digunakan dalam penelitian ini adalah deskriptif kualitatif dengan pengumpulan data berupa wawancara, observasi dan dokumentasi. Teknik analisis data menggunakan triangulasi metode Miles dan Huberman. Hasil penelitian menunjukkan bahwa program pendidikan karakter berbasis budaya sekolah sebagai penguat kewargaan pada siswa dengan membiasakan nilai-nilai utama karakter berupa religi, nasionalisme, mandiri, gotong royong dalam berbagai kegiatan budaya sekolah. Selain itu, terdapat dukungan dalam pelaksanaan program pendidikan karakter sebagai peningkat karakter kewirausahaan pada siswa Sekolah Dasar Ngrukeman Yogyakarta seperti sarana prasarana yang memadai dan pelatihan guru. Kesimpulan dari tulisan ini adalah bahwa program pendidikan karakter berbasis budaya sekolah sebagai penguat karakter kewargaan siswa di sekolah dasar dapat dilaksanakan dengan kerjasama berbagai pihak di sekolah. Rekomendasi dalam artikel ini supaya dapat mendalami lebih jauh tentang program pendidikan karakter berbasis budaya sekolah, khususnya di sekolah dasar.
\end{abstract}

\begin{abstract}
The development of the nation's character has not shown progress in the progress of its citizens to become more characterized. The phenomenon is that many people's behavior is not by the character imbued with the Pancasila philosophy. This study aims to analyze the program for strengthening character education based on school culture as a strengthening of the civic character of elementary school students. The method used in this research is descriptive qualitative with data collection in interviews, observations, and documentation. The data analysis technique uses the Miles and Huberman method triangulation. The results showed that the school culture-based character education program is a civic reinforcement for students by familiarizing the main character values in religion, nationalism, independence, cooperation in various school cultural activities. In addition, there is support in the implementation of character education programs as an enhancer of entrepreneurial character in Ngrukeman Yogyakarta Elementary School students, such as adequate infrastructure and teacher training. This paper concludes that the school culture-based character education program as a strengthening of the civic character of students in elementary schools can be implemented with the cooperation of various parties in the school. The recommendations in this article are to explore further the school culture-based character education program, especially in elementary schools.
\end{abstract}

\section{INTRODUCTION}

A person's success is influenced not only by the knowledge and skills possessed but also by the character possessed. Therefore, developing students' character is very important (Birhan et al., 2021; Grummich et al., 2017; Singh, 2019). The development of historical and socio-cultural characters has been the commitment of the Indonesian nation since its birth of the Indonesian nation. The development of the 
nation's character grows along with people's lives (Suastra et al., 2017; Wuryani \& Yamtinah, 2018). The concept of Bhinneka Tunggal Ika for the Indonesian people is defined as identity in diversity. However, in practice, building the nation's character has not shown progress in the progress of its citizens to become more characterized. The phenomenon is that many citizen behaviors are not by the character imbued with the Pancasila philosophy (Adibatin, 2016; Winataputra, 2016). Pancasila contains the nation's noble values that are upheld today (Andrew et al., 2019; Sudaryanti et al., 2015). Indonesian people are known for their friendly, polite, patient, cooperative attitude. However, many different citizens are easily angry, berate, spread hoaxes, and fight for signs of ethnic and religious differences. Even school children are not a few in the vortex of brawls, free sex, bullying, and hurting each other (Hidayah, 2015; Maunah, 2015).

The solution offered to overcome the problems of national values is to carry out cultural and character education (Puspoko Jati et al., 2019; Torimtubun et al., 2020). Based on Permendikbud No. 20 of 2018 article 2, the Strengthening Character Education program is implemented by applying the values of Pancasila in character education, especially including religious values, honesty, tolerance, discipline, hard work, creativity, independence, democratic, curiosity. , national spirit, love for the homeland, respect for achievement, communication, love peace, love to read, care for the environment, care for social, and be responsible (Rukiyati \& Purwastuti, 2016; Zuliani et al., 2017). The process of implementing massive character education will produce a young generation with civic character. Based on Permendikbud No. 20 of 2018 article 2, the Character Education Strengthening Program is implemented by applying the values of Pancasila in character education, especially covering religious values, honesty, tolerance, discipline, hard work, creativity, independence, democratic, curiosity, national spirit, love the homeland, appreciate achievement, communicative, love peace, love to read, care about the environment, care about social, and be responsible (Juneman et al., 2012; Sudaryanti et al., 2015). Elementary schools should carry out more character education content than secondary education units (Muhtar \& Dallyono, 2020; Prasetyo et al., 2020). The integration of character education content is carried out through extracurricular, curricular, and extracurricular programs. The process of implementing massive character education will produce a young generation with civic character.

Character is the nature or character, morals, or personality of a person obtained during their life (Asriani et al., 2017; Iswantiningtyas \& Wulansari, 2018). Having a good character is the foundation of soft skills that will support a person's level of success. Every human being must possess a positive character that must be built continuously (Maunah, 2015; Suhaida \& Fadillah, 2019). The teacher has to guide and strengthen each child to improve his behavior, way of life, and growth. Character education will keep the nation's personality in the character of the Indonesian nation. Character education is an activity carried out consciously through the learning environment to develop all the potential of students who have good character traits, have good morals, and have a positive, constructive effect on nature and society (Fahmy et al., 2015; Seijts \& Milani, 2021). Character education is closely related to moral education, which aims to form and train one's abilities for self-improvement towards a better life (Rokhman et al., 2014; Silanoi, 2012). Character education can form a person who is useful both for oneself and for many people. The main goal of character education is to build a tough nation with noble character, tolerance, and morality (Puspoko Jati et al., 2019; Qureshi et al., 2021). To achieve this goal, students must instill characterforming values originating from Religion, Pancasila, and Culture. Lack of character education will cause a moral crisis that will result in negative behavior such as promiscuity, drug abuse, theft, violence against children, and so on. This is why character education is very important for every human being. So that teachers, lecturers, and parents must instill good character values in children (Ferdiawan \& Putra, 2013; Kim, 2015).

The findings of previous research stated that the teacher's role as a facilitator in carrying out character education was a point of success and a means to meet the needs of teacher teaching hours. (Horasan-Doğan \& Cephe, 2020; Timmermans et al., 2019). Other research also states that character education is very important given to students to build positive character in students (Göthberg, 2019; Lee \& Huang, 2021). This is why character education is very important given to students. The purpose of the study was to analyze and explain the implementation of the KDP program as character strengthening for elementary school students. This research is expected to provide elementary school education, especially Pancasila and Citizenship Education in Elementary Schools.

\section{METHOD}

This research is a descriptive study with a qualitative approach by presenting data using words (Moleong, 2007). This research was conducted for 12 (twelve) months from January to December 2020 with the research location being Ngrukeman State Elementary School Yogyakarta. The target of this research is to find, explore, detail and record various kinds of things, especially regarding the character 
strengthening program as a civic character reinforcement. The data collection technique used is to use primary and secondary data collection. Primary data was conducted by conducting interviews with principals, vice principals, class teachers, and class students at Ngrukeman State Elementary School Yogyakarta using purposive sampling based on certain criteria or considerations. While the secondary data that is carried out in this research is to use literature studies that have a relationship or connection with the research carried out in order to complement the data obtained from primary data. Collecting data using observation where the researcher observes and is directly involved in activities in schools related to the civic character strengthening program. Furthermore, interviews with research subjects that have been previously determined by the researcher. In addition, the researchers also documented the results of observations, interviews, and collected school-related documents such as the school's vision and mission, school rules and regulations, written policies by the principal, posters for character education slogans. This process is carried out to find research objectives related to the instilled character, through preparation, implementation, evaluation, and follow-up plans. Data analysis uses the interactive model of Miles and Huberman (Miles et al., 1992), namely collecting data obtained from interviews, direct observation so that researchers are able to get a clearer and synchronized picture from the results of interviews, and analyze the documents that have been obtained. Furthermore, the researchers carried out data reduction as an effort to conclude the data that had been analyzed. Furthermore, the presentation of the data in the form of descriptive, and ends with the conclusion of the research results, which can then be processed into a scientific publication manuscript.

\section{RESULT AND DISCUSSION}

\section{Result}

Based on the formulation of the problem, the discussion in this research is to answer the implementation of the PPK program as a strengthening of the character of the citizenship in elementary school students. Based on the results of research at SD N Ngrukeman Yogyakarta about the implementation of the PPK program based on school culture in elementary schools, the results show that habituation is the main value at SD N Ngrukeman which is carried out through school culture. School culture can be one of the supports in improving student morale and achievement, such as the opinion of MacNeil, Prater, \& Busch that the development of school culture as a learning environment is the basis for improving teacher morale and student achievement. The habituation at SD Ngrukeman Yogyakarta which is related to school culture has several excellent character values, namely in the form of religion, nationalism, independence, mutual cooperation and integrated integrity in various school cultural activities. Following this, the researcher presents a superior value scheme in the implementation of the PPK program based on school culture at SD Ngrukeman Yogyakarta.

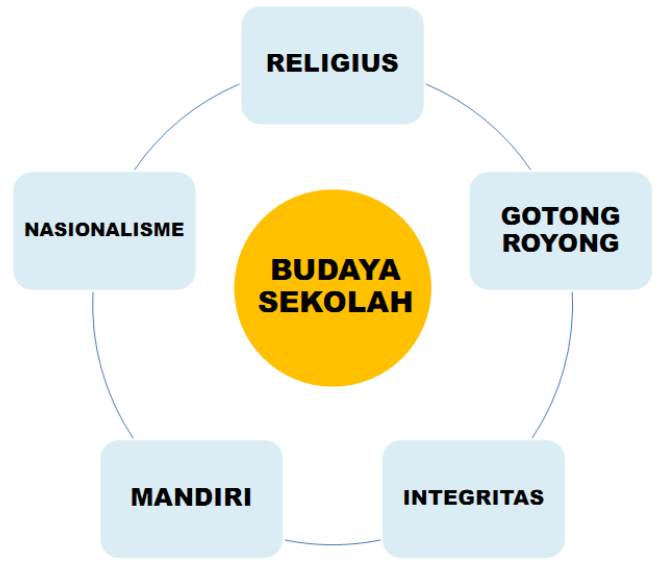

Figure 1. Superior Value in the Implementation of the School Culture-Based Character Education Strengthening Program at SD Ngrukeman Yogyakarta

Based on this opinion, the existence of superior values in the culture of SD N Ngrukeman Yogyakarta in the form of religious values, nationalism, independence, mutual cooperation and integrated integrity in various school cultural activities is the right effort in implementing the PPK program based on school culture in elementary schools. The character education program at SD N Ngrukeman Yogyakarta is structured by involving the principal, teachers, school committees, guardians and students. This cooperation is a manifestation of the seriousness of SD Ngrukeman Yogyakarta in implementing the PPK 
program based on school culture in elementary schools. Character education is not only the responsibility of some people, but involves other components such as schools, teachers, community parents, religious organizations and others. These components must work together in the success of developing character education. Thus at SD N Ngrukeman Yogyakarta, to develop character education, the active involvement of parents and the community has gone well.

In order to support good cooperation between components in schools, rules are needed as a basis so that the character education program is more directed (D. B. P. Pradana, 2017; Zuliani et al., 2017). The effectiveness of schools as a place to develop character is a shared responsibility among school members (Prasetyo et al., 2020; Puspoko Jati et al., 2019). The concepts of climate and organizational culture have become part of standardized rhetoric in contemporary discussions of school effectiveness. For SD N Ngrukeman Yogyakarta, setting school rules to develop character education is derived from the school's vision and mission. Supporting the findings of this study is the result of research examining the relationship between the mission statement and the performance of Primary Education Schools in Oman, using 161 school missions resulted in school principals spending a lot of effort designing school mission statements that direct schools to achieve their goals and improve their performance. SD N Ngrukeman Yogyakarta has school regulations that require school members to behave and behave well. The existence of school regulations makes teachers, students and other school members have clear directions for what should and should not be done (clear rules). The existing rules at SD Ngrukeman Yogyakarta are a supporter of the success of the character education program (PPK). Norms function to regulate practice and assess human behavior (Gross \& Vostroknutov, 2021; Heymann et al., 2019). Thus, the existence of rules at SD N Ngrukeman Yogyakarta becomes the basis for implementing PPK. SD N Ngrukeman Yogyakarta has $10 \mathrm{~K}$, namely faith, security, order, cleanliness, beauty, longing, health, cleanliness, openness, harmony which contributes to the formation of school culture. School culture is the quality of school life that grows based on the 5 main values of PPK. This is intended as the branding of the school itself. School culture is derived from the vision of the school. SD N Ngrukeman Yogyakarta which is a unique school has a vision of the realization of a clean and healthy school that is superior in achievement, has an environmental perspective, has character, and is based on faith and piety. The philosophy of Ki Hadjar Dewantara's character education is carried out by synergizing heart, exercise, thought and feeling.

The findings in the field of SD N Ngrukeman Elementary School Ngrukeman Yogyakarta character education through the environment are provided by schools through various activity programs, as well as providing space to express the character of students. The findings of this study are supported by the findings of research in the UK that explored student teacher attitudes and experiences of character education and values in schools and looked at their assessment of the opportunities provided by schools for character development. Research on 1000 teachers shows that although they are very supportive of their skills development in the area of moral development, their chances of doing this are uneven and depend on their course of study and their school placement. SD N Ngrukeman Yogyakarta provides activities that reflect environmental-based characters, such as disposing of garbage in its place, participating in community service activities, maintaining cleanliness and tidiness of the environment, taking care of plants and washing hands before and after activities. A healthy school as a branding for SD N Ngrukeman SD N Ngrukeman Yogyakarta is proven by the achievements that have been achieved, namely the 1st place in healthy schools in 2015. In addition, being a school ambassador to care about sanitation by reducing the use of plastic. This is indicated by the appeal of students to use a place to eat and drink that they bring themselves. The school canteen is reviewed by BPOM and the health office every month to see the quality of food that is sold and bought in the canteen. This shows that the school's efforts to create physically healthy students. The 2016 national level Adiwiyata School was also assigned to SD N Ngrukeman. The habit of caring for the environment is carried out through pickets regularly, using water wisely, and Friday clean.

The form of literacy that is given is for grades 1 and 2 listening and responding, while for grades 3-6 within 1 day you must read at least 1 non-lesson book. Regarding the form of literacy. The classroom setting at SD Ngrukeman Yogyakarta is made with a relaxed atmosphere and is not monotonous. The motivating character of the learning context can be enhanced through conscious intervention by the language teacher, and thus the main aspects of the environment will be discussed with proactive and practical goals in mind. The content of the books that students read contains character values such as febel books for the low class and folklore books for the high class. The second week of literacy is carried out with storytelling activities, namely telling stories about what students have passed or experienced, for example this morning I went to school to meet a vegetable seller, the third week of cultural literacy in 15 minutes, the teacher displays puppet characters in video form. The implementation of character education in schools needs to be habituated every day at any time.

The habituation of $5 \mathrm{~S}$ (smile, greetings, greetings, politeness, politeness) is a finding made by 
teachers for students and vice versa in interactions between school members. In addition, teachers and educators at SD Ngrukeman arrived early to welcome students with the $5 \mathrm{~S}$ habituation. Teacher exemplary is the key to the success of strengthening character education. In several previous studies it was found that teachers have a contribution to character education. The teacher provides examples of behavior that reflects the character of caring for the environment; through conditioning by providing and maintaining facilities and infrastructure that support environmental character education. The teacher gives an example then habituates good character to students. This is intended so that the five main character values are inherent and grow in students, indirectly giving birth to a young generation of character. In addition, it needs a good school ecosystem supported by quality human resources and good infrastructure. Implementation of strengthening character education (PPK) based on school culture in order to improve the competitiveness of students. It contains five dimensions discussed in this study, namely: 1) habituation of main values; 2) highlight the role models of adults in educational settings; 3 ) establish and comply with school norms, rules and traditions; 4) developing the uniqueness, excellence and competitiveness of the school as a characteristic of the school; and 5) developing the potential of students through extracurricular activities.

Character Education (PPK) is a government program to prepare the golden generation of 2045 . Permendikbud Number 20 of 2018 article 5 states that Strengthening Character Education (PPK) in formal education units is organized by optimizing the education trip center partnership function which includes: schools, families and communities. The content of character education in primary schools has a greater burden than secondary schools first or high school. Primary school is the first formal level of education in Indonesia that equips students with an understanding of knowledge, attitudes and skills for preparation for the next level. Character education in primary schools has more content than junior high or high school education units (Asriani et al., 2017; Cahyono et al., 2018). This makes primary schools have a contribution to shape and improve the character of young citizens. Ki Hadjar Dewantara put character (character) as the nature of humans. Humanizing humans can be done through civilized education and cultivating mutual tolerance (Maunah, 2015; Rukiyati \& Purwastuti, 2016). Although education is not the most frequently cited factor as an important factor, education rates very highly compared to others. In other words, education is the main dimension to hone not only intellectual knowledge but also character to be able to respect each other (Estuwardani \& Mustadi, 2016; Suryaningtyas et al., 2014). The main character values developed are religious, nationalism, independence, mutual cooperation and integrity, which are contained in all the learning activities and school culture at SD Ngrukeman Yogyakarta. These five values cannot stand alone, but work together to strengthen the character of young citizens' citizenship. There is religious value in SD N Ngrukeman Yogyakarta, namely starting and ending learning by praying together. In addition, pray together with dhuha and dhuhur according to each class schedule. The habit of worshiping together in order to strengthen the foundation of the religious values of students is carried out in its entirety. Students are trained in disciplinary malai preparation, implementation well.

Religious values merge into nationalism, independence, mutual cooperation and integrity (Y. Pradana, 2019; Sriyanto et al., 2019). These values are implemented in students through various school culture programs. Education has been considered a center of excellence in preparing superior human character (Indah Perawansa et al., 2019; Li et al., 2018). SD N Ngrukeman Yogyakarta, in a holistic way, is like the religious values of students starting and ending learning by praying, celebrating religious holidays, worshiping according to their respective religions. Infrastructure facilities in developing religious character are adequate, such as prayer rooms complete with facilities to support prayer activities. Religious values are the basis for developing the values of nationalism, self-reliance and integrity (Nudin, 2016; Salim, 2016). Nationalism is developed through the school culture at SD N Ngrukeman Yogyakarta, namely by singing the national song before the learning process takes place, routine flag ceremonies on Mondays and participating in ceremonies on other national holidays.

Character education in elementary schools, as an effort to strengthen the character of citizenship, namely to become a smart and good human being (smart and good citizen) (Indiarti, 2017; Narayani, 2019). In other words, to form citizenship character. Civic disposition includes a number of personality characteristics, namely: civility (respect and civil discourse), individual responsibility, self-discipline, civic-mindedness, open-mindedness (openness, skepticism, recognition of ambiguity), compromise (conflict of principles and limit to compromise), toleration of diversity, patience and persistence, compassion, generosity, and loyalty to the nation and its principles (Kurniawan, 2017; Suhaida \& Fadillah, 2019; Trisiana et al., 2019). Strengthening character education for the 5 main values through school culture at SD Ngrukeman as a small step in shaping civic character. Refraction based on religious values, nationalism, independence, mutual cooperation and integrity trains students to respect others, have responsibility, self-discipline, tolerance for diversity, and be loyal to their nation and country. 


\section{CONCLUSION}

Strengthening Character Education Program based on school culture as a strengthening of the civic character of students in elementary schools. instilling religious values, nationalism, independence, and mutual cooperation. Second, there is support in the implementation of strengthening character education program as a character strengthening for students at SD Ngrukeman Yogyakart such as a prayer room complete with facilities that support religious activities. Religious values are the basis for developing values of nationalism, self-reliance and integrity. Nationalism is developed through school culture at SD Ngrukeman, namely by singing the national song before the learning process takes place, routine flag ceremonies on Mondays and attending ceremonies on other national holidays.

\section{REFERENCES}

Adibatin, A. (2016). Pendidikan Karakter Bangsa Berbasis Strategi Pembelajaran PAKEM Melalui Permainan Cincin di Jempol Tangan (Karya Inovasi Pembelajaran Sekolah Dasar). Scholaria: Jurnal Pendidikan Dan Kebudayaan, 6(1), 1. https://doi.org/10.24246/j.scholaria.2016.v6.i1.p118.

Andrew, Henry, Yudhisthira, Arifin, \& Permai. (2019). Analyzing the Factors that Influence Learning Experience through Game Based Learning using Visual Novel Game for Learning Pancasila. Procedia Computer Science, 157. https://doi.org/10.1016/j.procs.2019.08.177.

Asriani, P., Sa'dijah, C., \& Akbar, S. (2017). Bahan Ajar Berbasis Pendidikan Karakter Untuk Siswa KElas IV Sekolah Dasar. Jurnal Pendidikan: Teori, Penelitian, Dan Pengembangan, 2(11), 1456-1468. http://dx.doi.org/10.17977/jptpp.v2i11.10160.

Birhan, W., Shiferaw, G., \& Tiruye, A. A. M. T. H. (2021). Exploring the context of teaching character education to children in preprimary and primary schools. Social Sciences \& Humanities Open, 4(1), 100171. https://doi.org/10.1016/j.ssaho.2021.100171.

Cahyono, B., Tsani, D. F., \& Rahma, A. (2018). Pengembangan Buku Saku Matematika Berbasis Karakter pada Materi Trigonometri. Jurnal Phenomenon, 08(2), 185-199. http://dx.doi.org/10.21580/phen.2018.8.2.2929.

Estuwardani, N. A., \& Mustadi, A. (2016). Pengembangan Bahan Ajar Modul Tematik-Integratif Dalam Peningkatan Karakter Peserta Didik Kelas I Sekolah Dasar. Jurnal Pendidikan Karakter, O(2), 157172. https://doi.org/10.21831/jpk.v0i2.8620.

Fahmy, R., Bachtiar, N., Rahim, R., \& Malik, M. (2015). Measuring Student Perceptions to Personal Characters Building in Education: An Indonesian Case in Implementing New Curriculum in High School. Procedia - Social and Behavioral Sciences, 211. https://doi.org/10.1016/j.sbspro.2015.11.112.

Ferdiawan, E., \& Putra, W. E. (2013). Esq Education for Children Character Building based on Phylosophy of Javaness in Indonesia. Procedia - Social and Behavioral Sciences, 106. https://doi.org/10.1016/j.sbspro.2013.12.123.

Göthberg, M. (2019). Cultivation of a deceiver - The emergence of a stage character in a student theatre production. Learning, Culture and Social Interaction, 22. https://doi.org/10.1016/j.lcsi.2019.02.005.

Gross, J., \& Vostroknutov, A. (2021). Why do people follow social norms? Current Opinion in Psychology, 1. https://doi.org/10.1016/j.copsyc.2021.08.016.

Grummich, P., Ganslandt, O., Buchfelder, M., \& Roessler, K. (2017). Characterization of a Factual Knowledge-Associated Brain Memory Area by Functional Magnetic Resonance Imaging and Implementation in Tumor and Epilepsy Brain Surgery. World Neurosurgery, 107. https://doi.org/10.1016/j.wneu.2017.07.176.

Heymann, P. J., Levy, J. K., Bose, B., Ríos-Salas, V., \& Mekonen, Y. (2019). Improving health with programmatic, legal, and policy approaches to reduce gender inequality and change restrictive gender norms. The Lancet, 393(10190). https://doi.org/10.1016/S0140-6736(19)30656-7.

Hidayah, N. (2015). Penanaman Nilai-Nilai Karakter Dalam Pembelajaran Bahasa Indonesia Di Sekolah Dasar. TERAMPIL: Jurnal Pendidikan dan Pembelajaran Dasar, 2(2), 190-204. https://doi.org/10.24042/terampil.v2i2.1291.

Horasan-Doğan, S., \& Cephe, P. T. (2020). The effects of creative drama on student teachers' creative pedagogy and identity. Thinking Skills and Creativity, 38. https://doi.org/10.1016/j.tsc.2020.100736.

Indah Perawansa, F., Minarni, A., \& Surya, E. (2019). Developing Learning Devices Based on GeoGebra Assisted Discovery Learning with SAVI Approach to Improve Motivation and Mathematical Communication of Senior High School Students MTs Aisyiyah. American Journal of Educational 
Research, 7(12), 893-900. https://doi.org/10.12691/education-7-12-1.

Indiarti, W. (2017). Nilai-Nilai Pembentuk Karakter Dalam Cerita Rakyat Asal-Usul Watu Dodol. Jentera: Jurnal Kajian Sastra, 6(1). https://doi.org/10.26499/jentera.v6i1.334.

Iswantiningtyas, V., \& Wulansari, W. (2018). Pengembangan model penilaian pendidikan karakter anak usia dini. Jurnal Pendidikan Usia Dini, 12(2). https://doi.org/10.21009/jpud.122.17.

Juneman, Meinarno, E. A., \& Rahardjo, W. (2012). Symbolic Meaning of Money, Self-esteem, and Identification with Pancasila Values. Procedia - Social and Behavioral Sciences, 65. https://doi.org/10.1016/j.sbspro.2012.11.099.

Kim, D. (2015). A Study on the Class of Education that Builds Students' Character Through Films - Classes at the University of Liberal Arts. Procedia - Social and Behavioral Sciences, 174. https://doi.org/10.1016/j.sbspro.2015.01.784.

Kurniawan, M. I. (2017). Meningkatkan Hasil Belajar Pendidikan Kewarganegaraan Melalui Strategi Active $\begin{array}{llll}\text { Learning. PEDAGOGIA: Jurnal } & \text { Pendidikan, }\end{array}$ https://doi.org/10.21070/pedagogia.v6i1.764.

Lee, C.-K. J., \& Huang, J. (2021). The relations between students' sense of school belonging, perceptions of school kindness and character strength of kindness. Journal of School Psychology, 84. https://doi.org/10.1016/j.jsp.2020.12.001.

Li, J., Zhang, X., \& Hu, Z. (2018). The design and application of flip classroom teaching based on computer technology. International Journal of Emerging Technologies in Learning, 13(10), 95-107. https://doi.org/10.3991/ijet.v13i10.9453.

Maunah, B. (2015). Implementasi Pendidikan Karakter dalam Pembentukan Kepribadian Holistik Siswa. Jurnal Pendidikan Karakter, 1. https://doi.org/10.21831/jpk.v0i1.8615.

Miles, Mathew, \& Huberman, M. (1992). Analisis Data Kualitatif Buku Tentang Metode Metode Baru. UI Press.

Muhtar, T., \& Dallyono, R. (2020). Character Education From the Perspectives of Elementary School Physical Education Teachers. Jurnal Cakrawala Pendidikan, 39(2), 395-408. https://doi.org/10.21831/cp.v39i2.30647.

Narayani, W. (2019). Pengaruh Model Pembelajaran Nht Berbasis Tri Hita Karana Terhadap Karakter Dan Hasil Belajar IPA. Jurnal Pendidikan Multikultural Indonesia., 2(1). http://dx.doi.org/10.23887/jpmu.v2i1.20785.

Nudin, B. (2016). Penanaman Nilai-Nilai Pendidikan Agama Islam Pada Pendidikan Anak Usia Dini Melalui Metode Montessori Di Safa Islamic Preschool. Millah: Jurnal Studi Agama, 16(1). https://doi.org/10.20885/millah.vol16.iss1.art3.

Pradana, D. B. P. (2017). Pengaruh Penerapan Tools Google Classroom pada Model Pembelajaran Project Based Learning terhadap Hasil Belajar Siswa. IT-Edu: Jurnal Information Technology and Education, 2(01).

Pradana, Y. (2019). Pengembangan Karakter Siswa Melalui Budaya Sekolah. Untirta Civic Education Journal, 1(1). http://dx.doi.org/10.30870/ucej.v1i1.1330.

Prasetyo, G., Hidayatullah, M. F., Akhyar, M., Wiranto, \& Perdana, R. (2020). Strengthening Students' Character Through Multimedia Learning In Primary Schools Education: Systematic LiteraturPrasetyo, G., Hidayatullah, M. F., Akhyar, M., Wiranto, \& Perdana, R. (2020). Strengthening Students' Character Through Multimedia Learning In . Humanities \& Social Sciences Reviews, 8(3), 268-277. https://doi.org/10.18510/hssr.2020.8328.

Puspoko Jati, D. H., Ismanto, B., \& Sulasmono, B. S. (2019). The Development of Local Wisdom Based Character Education Training Module. Journal of Education Research and Evaluation, 3(1), 1-9. https: //doi.org/10.23887/jere.v3i1.17763.

Qureshi, M. I., Khan, N., Raza, H., Imran, A., \& Ismail, F. (2021). Digital Technologies in Education 4.0. Does it Enhance the Effectiveness of Learning? A Systematic Literature Review. International Journal of Interactive Mobile Technologies (IJIM), https://doi.org/10.3991/ijim.v15i04.20291.

Rokhman, F., Hum, Syaifudin, A., \& Yuliati. (2014). Character Education for Golden Generation 2045 (National Character Building for Indonesian Golden Years). Procedia - Social and Behavioral Sciences, 141. https://doi.org/10.1016/j.sbspro.2014.05.197.

Rukiyati, \& Purwastuti. (2016). Model Pendidikan Karakter Berbasis Kearifan Lokal Pada Sekolah Dasar Di Bantul Yogyakarta. Jurnal Pendidikan Karakter, 1(1). https://doi.org/10.21831/jpk.v0i1.10743.

Salim, A. (2016). Pendekatan Saintifik Dalam Pembelajaran Pendidikan Agama Islam (Pai) Di Madrasah. Cendekia: Jurnal Kependidikan Dan Kemasyarakatan, 12(1). https://doi.org/10.21154/cendekia.v12i1.362.

Seijts, G. H., \& Milani, K. Y. (2021). The application of leader character to building cultures of equity, 
diversity, and inclusion. Business Horizons, 1. https://doi.org/10.1016/j.bushor.2021.07.007.

Silanoi, L. (2012). The Development of Teaching Pattern for Promoting the Building up of Character Education Based on Sufficiency Economy Philosophy in Thailand. Procedia - Social and Behavioral Sciences, 69. https:/doi.org/10.1016/j.sbspro.2012.12.131.

Singh, B. (2019). Character education in the 21st century. Journal of Social Studies (JSS), 15(1), 1-12. https://doi.org/10.21831/jss.v15i1.25226.

Sriyanto, Leksono, \& Harwanto. (2019). Bahan Ajar PPKn Berbasis Karakter dan Literasi Untuk Siswa Kelas IX SMP Al Hikmah Surabaya. Edmotech, 4(2), 130-142. http://dx.doi.org/10.17977/um039v4i22019p130.

Suastra, I. W., Jatmiko, B., Ristiati, N. P., \& Yasmini, L. P. B. (2017). Developing characters based on local wisdom of bali in teaching physics in senior high school. Jurnal Pendidikan IPA Indonesia, 6(2), 306-312. https://doi.org/10.15294/jpii.v6i2.10681.

Sudaryanti, D., Sukoharsono, E. G., Baridwan, Z., \& Mulawarman, A. D. (2015). Critical Analysis on Accounting Information Based On Pancasila Value. Procedia - Social and Behavioral Sciences, 172. https://doi.org/10.1016/j.sbspro.2015.01.399.

Suhaida, D., \& Fadillah, S. (2019). Media Kajian Kewarganegaraan membentuk karakter siswa. Jurnal Civics: Media Kajian Kewarganegaraan, 16(2), 11-121. https://doi.org/10.21831/jc.v16i2.21757.

Suryaningtyas, W., Suprapti, E., Solikin, A., \& Shoffa, S. (2014). Implementasi Lesson Study Berbasis Karakter Pada Mata Kuliah Statistika Dasar Dengan Menggunakan Media "Gabuz". Jurnal Pendidikan Dan Ilmu Pengetahuan, 14(1). http://dx.doi.org/10.30651/didaktis.v14i1.50.

Timmermans, A. C., Werf, M. P. C. G. van der, \& Rubie-Davies, C. M. (2019). The interpersonal character of teacher expectations: The perceived teacher-student relationship as an antecedent of teachers' track recommendations. Journal of School Psychology, 73. https://doi.org/10.1016/j.jsp.2019.02.004

Torimtubun, H., Arifin, S., \& Yarnest. (2020). Analysis of the Influence of Character, Compensation and Teaching Experience on Teacher Professionalism in the Kepulauan Tanimbar Regency of Indonesia. International Journal of Advances in Scientific Research and Engineering, 06(08), 74-81. https://doi.org/10.31695/ijasre.2020.33863.

Trisiana, A., Sugiaryo, \& Rispantyo. (2019). Implementasi Pendidikan Karakter Dalam Pendidikan Kewarganegaraan Sebagai Inovasi Pengembangan Di Era Media Digital Dan Revolusi Industri 4.0. Jurnal Global Citizen: Jurnal Ilmiah Kajian Pendidikan Kewarganegaraan, 7(1). https://doi.org/10.33061/jgz.v7i1.3059.

Winataputra, U. S. (2016). Multikulturalisme-Bhinneka Tunggal lka Dalam Perspektif Pendidikan Kewarganegaraan Sebagai Wahana Pembangunan Karakter Bangsa Indonesia. Jurnal Pendidikan Dan Kebudayaan, 14(75). https://doi.org/10.24832/jpnk.v14i75.364.

Wuryani, M. T., \& Yamtinah, S. (2018). Textbooks Thematic Based Character Education on Thematic Learning Primary School: An Influence. International Journal of Educational Methodology, 4(2), 75-81. https://doi.org/10.12973/ijem.4.2.75.

Zuliani, D., Florentinus, T. S., \& Ridlo, S. (2017). Pengembangan Instrumen Penilaian Karakter pada Siswa Kelas IV Sekolah Dasar. Journal of Research and Educational Research Evaluation, 6(1). https://doi.org/10.15294/jrer.v6i1.16207. 